\title{
Reframing the sustainable development goals to achieve sustainable development in the Anthropocene-a systems approach
}

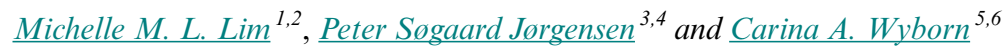

\begin{abstract}
Griggs et al. (2013) redefine sustainable development as "development that meets the needs of the present while safeguarding Earth's life-support system, on which the welfare of current and future generations depend." We recommend this as the end goal that the United Nations sustainable development goals (SDGs) should strive to achieve. Integration across the SDGs is less than what is required from a science perspective. Effective implementation of the SDGs will require States to attend to trade-offs and overlaps. We argue that continuous failure to address integration within the SDGs will jeopardize realization of this ultimate end goal. Therefore, we adopt a systems approach to identify gaps and connections across the goals and targets of the SDGs as well as leverage points for effective intervention. We triangulate across methods of critical analysis, conceptual modeling, and keyword network analysis to draw out seven "overarching directions" that could provide a prioritization framework to enhance efficient implementation of the SDGs. Our results identify main gaps as exclusion of key actors (e.g., corporations) and issues (e.g., intergenerational equity and population); inadequate reconciliation of economic growth with maintaining the Earth system; and deficient consideration of the relationship with international law. Conceptual mapping identifies education and innovation; governance and implementation; sustainable consumption and production; and addressing the key drivers of climate change as key leverage points. The keyword analysis highlights greater integration within the SDGs than what appears at face value. Keywords "access," "women," "resources," and "finance" feature across the SDGs and provide further leverage points. Targeting these issues will facilitate realization of a high proportion of SDGs and correspondingly could have a disproportional impact on effective SDG implementation. We conclude that the success of the SDGs needs to be evaluated by the extent to which it contributes to human development while advancing protection of "planetary must-haves" for current and future generations.
\end{abstract}

Key Words: implementation, sustainable development goals; systems approach

\section{INTRODUCTION}

There is an urgent need for an integrated approach that maintains Earth's life-support systems while ensuring continued social progress (Steffen et al. 2015). To this end, the United Nations' sustainable development goals (SDGs) aim to provide an actionoriented road map "of critical importance for humanity and our planet” (United Nations (UN) 2015).

Prior to their adoption in September 2015, many warned that the urgency of averting catastrophic global change meant that failure to capitalize on the opportunity of the SDGs would be a global disaster (Griggs et al. 2014, Young et al. 2014, Costanza et al. 2015). This concern was paired with calls to extensively revise the published draft of the SDGs (the Open Working Group (OWG) draft) (Griggs et al. 2014, Young et al. 2014, Costanza et al. 2015). States, however, resisted changes to the OWG draft for fear of disrupting the delicate political balance achieved in their formulation. Consequently, although many goals contain the environmental, social, and economic dimensions of sustainability, integration across the overall framework remains insufficient (Nilsson and Costanza 2015).

Moreover, Costanza et al. (2015) caution that without an explicit end goal, the SDGs are missing a critical element for success. Given the inevitable trade-offs that will need to be reconciled, we argue that an overarching principle or "end goal" provides crucial guidance for implementation of individual goals and targets. An end goal will also facilitate resolution of competing interests when multiple interests and objectives inevitably collide.

In this paper, we adopt the Griggs et al. (2013) redefinition of sustainable development as the end goal to which multiple components of the SDGs should be directed. Griggs et al. (2013) draw on the planetary boundaries framework (Rockström et al. 2009, Steffen et al. 2015) to reenvisage the Brundtland definition of sustainable development as "development that meets the needs of the present while safeguarding Earth's life-support system, on which the welfare of current and future generations depend." We recommend this redefinition of sustainable development as the end goal that the SDGs should strive to achieve. We argue that if integration across the SDGs is not addressed then the SDGs will fail to contribute to the sustainable development end goal.

We take the need for integration, means to address trade-offs, and an end goal as our starting points. We adopt a systems approach (Meadows 1999, Liu et al. 2015) and interdisciplinary triangulation across methods to identify gaps and connections across the goals and targets of the SDGs. First, we expand on the importance of integration across the goals. Our critical analysis of the SDG text identifies areas within and across the goals and targets that impede or conflict with the sustainable development end goal. We combine conceptual modeling of the 17 goals with keyword network analysis at the level of targets. From these analyses, we recommend seven "overarching directions" as a

\footnotetext{
${ }^{1}$ Adelaide Law School, University of Adelaide, ${ }^{2}$ Environment Institute, University of Adelaide, ${ }^{3}$ Global Economic Dynamics and the Biosphere, Royal Swedish Academy of Sciences, ${ }^{4}$ Stockholm Resilience Centre, Stockholm University, ${ }^{5}$ Luc Hoffmann Institute, IUCN Conservation Centre, Rue Mauverney 28, 1196 Gland, Switzerland, ${ }^{6}$ Department of Society and Conservation, University of Montana, 32 Campus Drive, Missoula, Montana, 59801, USA
} 
prioritization framework for resource distribution and effective implementation of the SDGs. We conclude that the success of the SDGs needs to be measured in terms of whether the goals and the broader 2030 Agenda support human development and advance protection of "planetary must-haves" for current and future generations (Griggs et al. 2013). It is to this larger end goal that this paper ultimately aims to contribute.

\section{FAILURE TO INTEGRATE ACROSS THE SUSTAINABLE DEVELOPMENT GOAL SYSTEM WILL UNDERMINE THE END GOAL OF SUSTAINABLE DEVELOPMENT WITHIN PLANETARY BOUNDARIES}

Many sustainability challenges are closely intertwined (Liu et al. 2015) and often involve complex, self-organizing systems (Hjorth and Bagheri 2006). Achieving sustainability therefore requires societies to address the spectrum of interacting biophysical, social, economic, and governance issues. Scientific discourses predominantly address these issues from disciplinary perspectives in a compartmentalized manner (Abson et al. 2017). Reductionist efforts focused on individual components can overlook critical interactions in the global system and be unintentionally counterproductive in achieving global sustainability. Systems integration is therefore essential to create sustainability solutions in linked human-environment systems (Liu et al. 2015).

Systems approaches appreciate that a singular focus on component parts provides an incomplete picture of complex problems and rarely leads to long-term solutions. The approach provides a multidimensional means of considering the various interacting components of the world. It places equal emphasis on identifying and describing the interactions between objects in the system, as it does the objects themselves (Clayton and Radcliffe 1996). The approach seeks to identify feedbacks in the system where impacts on one component can set up a recurring cycle of direct or indirect impacts on other components of the system.

Integrated systems-oriented approaches are necessary to address the complexity of social-ecological systems (Fischer et al. 2015). Abson et al. (2017) underline how systems thinking has proved valuable in advancing sustainability science, particularly in areas of resilience (Folke et al. 2010), transitions management (PahlWostl 2007), and transformational sustainability research, and in disciplines ranging from economics (e.g., Arthur 1994) to public administration (e.g., Kickert et al. 1999) to the social sciences (e.g., Ostrom 2009). Abson et al. (2017) also highlight specific examples of how systems thinking in the Ghanaian agricultural sector revealed essential relationships across policy, social, and environmental dimensions of the sector (Banson et al. 2015), and that agricultural intensification can increase the rate of expansion of agricultural land (Phelps et al. 2013). Systems thinking therefore provides an essential lens for approaching sustainability.

The SDGs reflect traditional compartmentalization of sectors and are presented in a siloed manner. The multiple components of the SDGs are therefore largely contained within conventional sectors (Nilsson and Costanza 2015). Individual SDGs are discussed as separate elements mostly in isolation from each other (Nilsson and Costanza 2015, Costanza et al. 2015). There is minimal crossreferencing across goals and limited recognition of the potential conflicts between individual goals. Consequently, the framework as a whole may not be internally consistent and could therefore undermine the ultimate end goal of sustainable development (Nilsson and Costanza 2015).

There have been multiple calls to recognize the interactions and links between goals and targets, as well as the necessary trade-offs that need to occur (Weitz et al. 2014, Deacon and St. Clair 2015, International Council of Science / International Social Science Council (ICSU/ISSC) 2015, Nilsson and Costanza 2015, Nilsson et al. 2016). Demonstrating the interrelationships between goals and targets and responding to all goals as an integrated whole is critical to ensure the transformations required for sustainable development (Ban 2014). Such integration could be achieved by the framing of crosscutting and integrative goals to bridge sectoral silos (Young et al. 2014) and by using a systems approach (Nilsson and Costanza 2015).

Global goals set prescriptive norms to guide actions that should lead to intended behavior change (Fukuda-Parr 2014). If the importance of an integrated approach to the SDGs is not emphasized, there is the high risk that States will "cherry pick" components of the SDGs that align with existing national priorities at the expense of goals, such as those aligned with Earth's life-support system, which are more difficult to implement (Stafford-Smith et al. 2016).

Given their power in directing behavior and setting norms for policy, it is critical to develop an implementable and integrated framework for the SDGs oriented toward the sustainable development end goal. We argue that systems approaches provide a foundation for integration within the SDGs and ultimately achieving the sustainable development end goal.

\section{METHODS}

In this paper, we aim to visualize clusters of targets and goals that may require close coordination. The systems approach adopted here is underpinned by triangulation across three different methods. Triangulation is the mixing of data or methods to study the same phenomenon. This enables diverse viewpoints to cast light upon a topic (Denzin 1989, Olsen 2004). The three methods used are: critical analysis of the goals and targets, conceptual modeling (Newell et al. 2011) of the 17 goals, and keyword network analysis of the 17 goals and 169 targets (Fig. 1).

Our approach appreciates the highly complex nature of the SDGs and the multiple sectors and scales across which they are implemented. Relying on any one method would only provide partial insight. Therefore, we combine methods to articulate connections and identify areas where further research is needed. By viewing the SDG system through multiple lenses, the paper identifies connections and gaps within the SDG framework. These approaches facilitate clustering in seven overarching directions to enable focused and integrated implementation of the SDGs and ultimately realization of the sustainable development end goal defined above.

\section{Critical analysis}

Critical analysis enables identification of latent meaning as well as implicit patterns, assumptions, and omissions within a text (Fürsich 2009). Critical analysis in this paper consists of an evaluation of the extent to which the SDG text facilitates 
realization of the sustainable development end goal. The critical analysis feeds into the conceptual modeling to assist in succinct definition of each of the goals. This facilitates conceptual modeling by allowing the goals to be precisely defined so that the interactions between each of the goals can be mapped in a purposeful manner.

Fig. 1. Flowchart of the relationships among the three types of methods: textual analysis, conceptual modeling, and keyword network analysis.

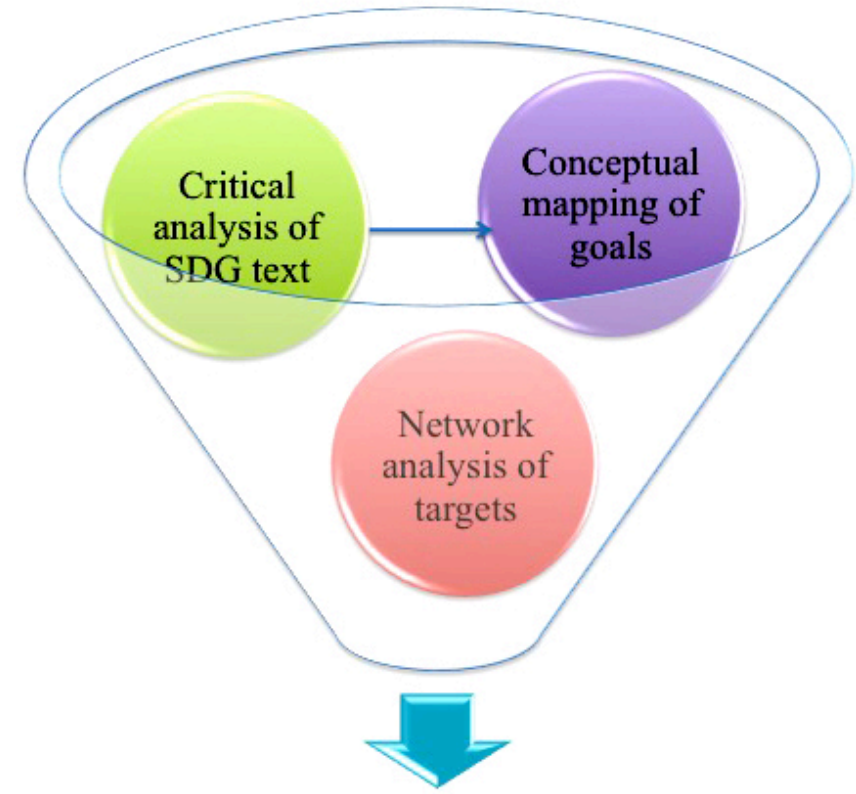

Integration priorities and key links across the SDGs necessary to achieve the sustainable development end goal

\section{Conceptual modeling}

Conceptual models can provide useful insights into interactions and feedbacks among components of a given system (Hjorth and Bagheri 2006, Meadows 2008, Proust et al. 2012). Modeling in this paper takes the form of "influence diagrams." Influence diagrams are visual representations of tentative dynamic hypotheses. The diagrams identify the components of the system and highlight the links between the components (Newell et al. 2011). Given the scope of the SDGs, it is important to think expansively and qualitatively about the nature of the goals and their targets and the issues that the goals aim to address, and to form a preliminary understanding of where key interactions are within the SDGs. The aim of this approach is to provide qualitative insights into relationships to form the basis of future quantitative analysis.

Identifying meaningful interactions and connections across the goals requires a precise definition of each goal. We draw on the critical analysis to facilitate further critical thinking about whether individual goals and the SDGs as a whole were fit for purpose, and we used the targets to interpret the meaning of each goal. To facilitate understanding of the interactions between the goals and where integration might occur, the goals and the interactions between them are mapped in an influence diagram (see Fig. 2). An influence diagram of the SDGs is constructed at the level of the goals, with the goals forming the variables of the system. We identify basic relationships between the goals to map out interconnections and trade-offs across the SDGs. These results facilitate identification of which relationships should be examined in further depth to understand directionality.

Leverage points are points in a system where interventions are likely to have a disproportionate impact and require the least amount of resources to create a change in the system (Meadows 1999). Leverage points, overlaps, important interactions, and gaps within the SDGs were identified through the diagrammatic mapping of the goals (see Fig 2). Textual analysis through the lens of the end goal, combined with identification of interactions and overlaps through conceptual modeling, enables goals to then be clustered into overarching directions. Clustering in the form of overarching directions facilitates effective and efficient implementation of the SDGs by highlighting key interactions that need to be addressed to achieve the end goal, as well as goals that could be achieved simultaneously.

\section{Keyword network analysis}

Drawing on the millennium development goals (MDGs), Griggs et al. (2014) suggest that quantifiable targets could be more important than broad goals for focusing efforts. They suggest that single-issue targets need to be complemented by targets that deliberately address interactions. Such targets, they suggest, could focus on the interdependencies between two or more topics to ensure that these issues are tackled in an integrated way. By mapping shared keywords, the network analysis aims to demonstrate the degree to which targets address shared challenges. This is achieved by identifying commonalities across subjects (e.g., women) and interventions (e.g., resources, finance, and accessibility). By revealing connections across seemingly unrelated targets, we broaden opportunities for cross-sectoral collaboration. This improves understanding of the extent of integration across the SDG framework or whether targets are clustered in silos (e.g., environmental, economic, or social).

We mapped five categories of keywords:(1) Challenges - the topic addressed by the target, e.g., climate change; (2) Subjects- the thing or persons affected or addressed by a target, e.g., developing countries or women; (3) Instruments and conditions - a tool with to achieve the target or a condition under which the target should be achieved, e.g., regulation or national circumstances; (4) Actions - the verb to achieve the target, e.g., prevent or ensure; (5) Properties - challenges and issues that clarify the overarching topical challenge, e.g., improving access to a resource or service. These five categories of keywords were chosen to extend the focus of analysis beyond merely examining challenges and topics (cf. Le Blanc 2015) to also incorporate stakeholders (i.e., subjects); second-order, enabling, or constraining characteristics (properties, instruments, and conditions); and types of interventions (i.e., actions). Keywords were identified from the SDG text and mapped under the following content categories: topical challenges, subjects, instruments and conditions, actions, properties. Keywords were identified from the SDG text and mapped under the following content categories: topical challenges, subjects, actions, properties. 
Fig. 2. Influence diagram of the SDGs: illustrating links among the SDGs. Some goals have been split into subgoals to facilitate more precise mapping. Arrows highlight where one goal is likely to have an impact on another goal. The arrowhead represents the goal that is impacted. There is no value attached to the type of impact (i.e., it could be a positive or negative impact). The arrows just illustrate that a relationship exists.

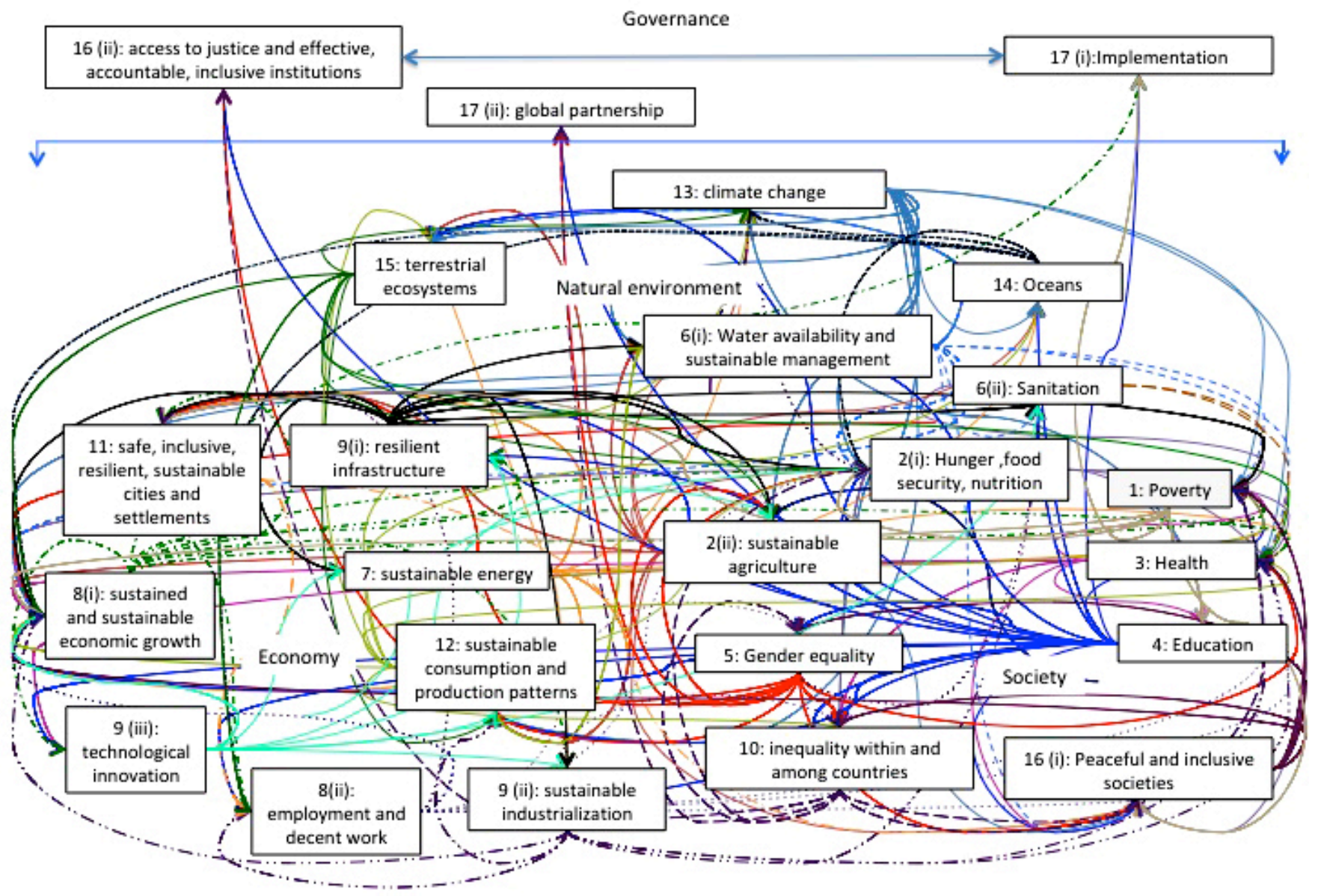

For example, in Target 4.3 ("By 2030, ensure equal access for all women and men to affordable and quality technical, vocational and tertiary education, including university"), the topic is the three types of education, the subjects are "all women and men," the properties map to "equal access" and "affordable and quality." An example of instruments and conditions can be found in the phrase "developed countries taking the lead" in Target 12.1.

We performed keyword-based network analysis of target-totarget links between 126 of the 169 SDG targets (Jørgensen, unpublished manuscript). This analysis included all the numbered targets (e.g., Target 1.1, 1.2, etc.) of SDGs 1 to 16 . Following Le Blanc (2015), implementation-related goals and targets (i.e., lettered goals and targets of SDG17) were omitted to focus analysis on targets of a similar nature.

The more than 1,000 unique keywords were used for network construction, to compare connectivity, and to identify the number of subnetworks. This ultimately revealed integrating targets and keywords that link the SDG targets together across seemingly disparate goals. Using the "graph.incidence" function in R and a bipartite projection, two general types of undirected incidence networks were computed: (1) with keywords as edges and targets as vertices, (2) with keywords as edges and goals as vertices (see Jørgensen (unpublished manuscript) for further detail).

\section{RESULTS}

Gaps and shortcomings of the sustainable development goals Critical analysis of the SDGs suggests an overly ambitious and insufficiently integrated global agenda that could potentially undermine the sustainable development end goal. The analysis suggests that, although the SDGs may "meet the needs of the present" within its 15-yr timeframe, if taken at face value, the SDGs could jeopardize "Earth's life-support system" and the welfare of future generations. Explicit crossreferencing across the 17 goals and 169 targets is absent, and inconsistencies in approach, particularly as they pertain to the implementation targets, lead to a document that has the appearance of authorship by 17 disconnected committees. Key shortcomings include that the SDGs prioritize economic growth and frame it as the solution to poverty; the haphazard incorporation of international law; the omission of a crucial actor: corporations; and failure to 
adequately address essential issues such as population and temporal concerns to achieve intergenerational equity and longterm sustainability.

Narrow conceptualization of poverty and overly ambitious aims for poverty eradication

SDG1 ("End poverty in all its forms everywhere") reveals an oversimplification of "poverty" that ignores decades of research and practice that highlight the multiple dimensions of poverty and the conceptualization of poverty through a livelihoods lens (see, e.g., Chambers and Conway 1991, Sen 1999, Dasgupta 2001, Morse and McNamara 2013b, Reed et al. 2013). Nilsson and Costanza (2015) point to the lack of a clear articulation of Sen's key "freedoms," such as economic opportunities, political liberty, social empowerment, dignity, and good health and education (Sen 1999). Although each of these elements appears in the SDGs, there is a lack of coherence across these "freedoms" and limited understanding of the cumulative impacts these elements have on poverty. This is also at odds with the former Secretary-General's acknowledgment that poverty measures should reflect the multidimensional nature of poverty and consider subjective measures of well-being (Ban 2014).

Sustainable development goal 1 (SDG1) treats poverty as equal wherever it may occur. Although seemingly comprehensive, the lack of focus leaves the goal open to being construed in a way that fails to address marked differences in the reality of poverty in different countries. At worst, it could lead to wealthier nations focusing first on addressing poverty needs "at home," leaving the much greater deprivation in the poorest nations as an afterthought.

Stafford-Smith et al. (2016) stress the importance of interlinkages between and among low-, medium-, and high-income nations. This is particularly crucial for SDG1 to ensure the advancement of human development "everywhere." However, SDG 1 does not facilitate the redistribution and restructuring of wealth required to address poverty as a global issue. Similarly, in reference to the targets, Deacon and St. Clair (2015) call out the omission of national and international processes of wealth creation, redistribution, and associated regulatory regimes. The SDGs also lean toward purely economic definitions of poverty (see, e.g., Target 1.1 where extreme poverty is defined as $\$ 1.25$ a day). Sustainable development goal 2 focuses on nutrition and food security, and SDG 3 on health. In overarching direction 2, below, we suggest clustering of these three goals to facilitate integrated implementation within broader understandings of poverty.

Is sustained growth sustainable?

Sustainable development goal 8 raises significant sustainability alarm bells. The goal aims to "Promote sustained, inclusive and sustainable economic growth, full and productive employment and decent work for all." Le Blanc (2015) points out that in the implementation of the MDGs, the "environmental sustainability" goal (MDG 7) was ultimately undermined by other goals. Similarly, in the context of the SDGs, failure to consider systematic implementation of the SDGs as a whole could lead to perverse outcomes that undermine Earth's life-support system (Stafford-Smith et al. 2016). Sustainable development goal 8 is a clear example of where this could occur. The risk is that all targets of SDG 8 could be successfully realized while jeopardizing other SDGs, particularly those related to the environment, and ultimately the sustainable development end goal.
Only Target 8.4 hints at some consideration of sustainability, with calls for increased efficiency in consumption and production. Yet it only "endeavors" to decouple economic growth from environmental degradation, leaving sustained growth as the clear objective. Target 8.1 for example aims to sustain per capita economic growth generally and by at least $7 \%$ gross domestic product growth per annum in least developed countries.

Industrialization in SDG 9 risks undermining the end goal further. The goal and its targets use phrases such as "inclusive" and "sustainable" but fail to acknowledge the inevitable environmental and potential social impacts of transforming agrarian economies to those based on manufacturing. Target 9.2's objective to significantly raise industry's share of employment and gross domestic product and to double this share in developing countries is particularly troubling as it suggests a continued economic trajectory based on increased industrialization rather than diversification into more environmentally sustainable livelihood options. Furthermore, although Target 9.4 promotes green technologies, the focus on increased industrialization and production remains.

The preamble of the 2030 Agenda pledges that in implementation of the SDGs "no one will be left behind" (UN 2015c). The former Secretary-General emphasized the need for economic transformation through a more equitable multilateral trading system that addresses inequities that have long plagued the international system (Ban 2014). At the same time, enhanced equity across a range of sectors and issues is an aspiration of many of the SDGs. Despite this, the SDGs do little to directly target global structural inequities, thus falling short of the truly transformative measures required to address the inequity concerns highlighted by the goals.

Yamada (2017) highlights that the corporate sector will play a key role in the success or otherwise of the goal-based governance of the SDGs. Corporations, however, only feature in the SDGs once, in relation to the reduction of waste generation in Target 12.6. Given their power at multiple scales, this critical omission has been called out as deliberate and may be symptomatic of the lack of truly transformative intentions of state parties in the framing of the SDGs (see Brewer 2015). Whether by design or oversight, their absence limits the potential of the SDGs to bring about the socioeconomic restructuring required to achieve sustainability.

\section{Haphazard inclusion of international law and ratification by stealth}

The inconsistent approach to legal and institutional components of the SDGs is a significant weakness. Although their inclusion is laudable, the content of the implementation targets under each goal varies markedly. Only three conventions are explicitly included in the SDGs: the United Nations Framework Convention on Climate Change (in SDG13); the United Nations Convention on the Law of the Sea (in SDG14), and the Framework Convention on Tobacco Control (in SDG 3), whereas SDG 10 refers to "World Trade Organisation agreements." The goals and targets do not contain reference to any of the biodiversity related multilateral agreements nor any of the human rights conventions. There is cursory reference to some of these instruments in the Agenda's Declaration. 
The haphazard inclusion of multilateral conventions in the SDGs underlines a lack of consistency and integration that could undermine the strength of implementation. Issues targeted by a range of conventions are included throughout the SDG text. This does not equate, however, to recognizing the Conventions themselves as the tool through which the SDGs will be realized. The explicit naming of some Conventions and not others suggests to States that, for the purpose of meeting the SDGs, commitments under listed Conventions are more important than commitments under other multilateral agreements.

Including conventions as part of global goals is itself problematic. Under international law, nation states are only bound to the extent they agree to be bound (see, e.g., Permanent Court of International Justice (PCIJ) 1927). Most (although not all) countries have ratified the conventions that are explicitly referred to in the SDGs. Requiring all countries to implement the SDGs through explicitly named conventions could lead to "ratification by stealth," where nonsignatory countries will be required to give effect to convention obligations that they have not signed up to. This could create an implementation problem where nonsignatory states refrain from endorsing coordinated approaches under certain goals to avoid tacit acceptance of the conventions included in the SDGs.

\section{Intergenerational and population concerns}

Intergenerational equity and population ought to have received greater attention in the SDGs. Central to both the Brundtland (World Commission on Environment and Development (WCED) 1987) definition of sustainable development and the Griggs et al. (2014) redefinition adopted as the end goal in this paper, is the principle of intergenerational equity. The principle has been repeatedly recognized as fundamental to sustainable development (Schrijver 2002, Sands 2003, French 2010). Despite this, there is no explicit reference to intergenerational equity in either the goals or targets. "Future generations" does, however, appear in the text of the Agenda's Declaration. Furthermore, the timeframe outlined in the SDGs stops at 2030, yet, the ethos of sustainability outlined in the "end goal" as well as the Brundtland Report and the UN Conventions requires thinking far beyond $15 \mathrm{yr}$.

Insufficient consideration of the temporal dimension of sustainable development is also evident in the absence of explicit targeting of population issues. Although human population reduction will not immediately solve environmental problems (Bradshaw and Brook 2014), if actively tackled, it has the potential to deliver important long-term sustainability (Bradshaw and Brook 2014) and climate-related (O'Neill et al. 2012) benefits.

The goals address reproductive (Target 3.7) and universal (Target 3.8) health care as well as drivers of decreased fertility such as family planning (Bongaarts and Sinding 2011) (Target 3.7), the empowerment of women (Lutz 2009, McCrary and Royer 2011) (SDG 5), and education (Skirbekk 2008, Lutz 2009, Bradshaw and Brook 2014) (SDGs 3, 4). However, although a decrease in per capita fertility has been observed over the last few decades (see Bradshaw and Brook 2014), the global human population is unlikely to stabilize this century (Gerland et al. 2014). Furthermore, the decrease in population growth has occurred unevenly across the world (Cohen 2003, Gerland et al. 2014). Rapid population growth in high fertility countries will create significant environmental, economic, health, governance, education, and social challenges (Gerland et al. 2014) — areas that are key concerns of the SDGs. Given the clear global environmental and social benefits to continued fertility reduction (Bradshaw and Brook 2014), we suggest a coordinated approach to population growth that brings together the goals and targets related to population growth in a focused way.

The critical analysis of the SDGs highlights key gaps and weaknesses in the SDG framework. Below, we attempt to bridge these gaps through conceptual mapping and network analysis.

\section{Conceptual modeling}

Four subsystems (Society, Economy, Natural Environment, and Governance) were identified at the outset to facilitate mapping of the SDG system. This underlined the disproportionately few number of environment-related goals in the SDGs. Griggs et al. (2014) also observed juxtaposition of reasonably well-developed social and economic goals, including some well-quantified targets with limited integration of environmental sustainability goals and few quantified environmental targets. Mainstreaming environmental considerations throughout the SDGs (unlike the explicit environmental goal in the MDGs), could facilitate further progress and a more integrated approach. However, without explicit environmental targets nested underneath each goal, the accountability mechanisms to ensure mainstreaming are weak.

The identification of subsystems highlighted the need for greater strategic orchestration in formulating goals and targets. For example, sustainable water resource management and sanitation are combined in SDG 6. Although the links to clean drinking water and sanitation are clear, it also means that the environmental importance of water is potentially overlooked. There was the need to divide some goals into component parts to facilitate greater precision in mapping relationships. SDGs 2, 6, $8,9,16$, and 17 were split into two or more components as multiple disparate issues were addressed in the same goal (see Appendix 1).

Dividing SDG 8 into economic growth SDG 8(i) and employment 8(ii) enabled analysis of the impact of economic growth on the components of the system and the multiple interactions that other goals had on achieving economic growth. This highlighted the importance of a strong economy to goals focused on implementation and institutional and human well-being, particularly in the short term. Separating employment (8(ii)) from economic growth also facilitated broader thinking about the contributors to decent work beyond the formal economy. Splitting up SDG 9 into three subgoals enabled the importance of resilient infrastructure to be highlighted.

Once the variables were articulated, links were identified between each variable and connected to each other by arrows representing connections between the goals (Fig. 2). The discussion below highlights how systematic consideration of relationships between each of the goals instigated further thinking about the diverse goals that may have otherwise been overlooked.

Leverage points and overlaps identified from conceptual modeling The conceptual mapping suggests where key links and leverage points are across the system. The results of the mapping are described qualitatively below.

Figure 2 and Table 1 reveal that most goals are closely linked to other goals. Leverage points were identified by determining which 
Table 1. Number of links across SDGs and subgoals. The table sets out the number of SDGs that each SDG (or subgoal) has an impact on and the number of SDGs (or subgoals) that impact on the realization of each SDG (or subgoal).

\begin{tabular}{|c|c|c|}
\hline \multirow[t]{2}{*}{ Sustainable development goals and subgoals } & \multicolumn{2}{|c|}{ No. of SDGs/subgoals that this SDG/subgoal } \\
\hline & has an impact on & is impacted by \\
\hline SDG 1: Poverty & 5 & 16 \\
\hline SDG 2 (i): Hunger, food security, and nutrition & 3 & 15 \\
\hline SDG 2(ii) Sustainable agriculture & 9 & 6 \\
\hline SDG 3: Health & 6 & 12 \\
\hline SDG 4: Education & 17 & 4 \\
\hline SDG 5: Gender equality & 8 & 4 \\
\hline SDG 6(i) Water availability and sustainable management & 6 & 4 \\
\hline SDG 6 (ii) Sanitation & 2 & 6 \\
\hline SDG 7: Sustainable energy & 9 & 3 \\
\hline SDG 8 (i) Sustained and sustainable economic growth & 10 & 19 \\
\hline SDG 8(ii) Employment and decent work & 8 & 6 \\
\hline SDG 9 (i) Resilient infrastructure & 8 & 3 \\
\hline SDG 9 (ii) Sustainable industrialization & 6 & 2 \\
\hline SDG 9 (iii) Technological innovation & 6 & 4 \\
\hline SDG 10: Inequality within and among countries & 6 & 9 \\
\hline SDG 11: Safe, resilient, and sustainable cities and settlements. & 2 & 9 \\
\hline SDG12: Sustainable consumption and production. & 7 & 9 \\
\hline SDG 13: Climate change & 9 & 6 \\
\hline SDG 14: Oceans & 4 & 6 \\
\hline SDG 15: Terrestrial ecosystems & 6 & 7 \\
\hline SDG16(i) Peaceful and inclusive societies & 5 & 12 \\
\hline SDG 16 (ii) access to justice and effective, accountable, inclusive institutions & Overarching goals that & 3 \\
\hline SDG 17(i) Means of implementation & contribute to the realization & 4 \\
\hline SDG 17(ii) Global partnerships & of all other goals & 3 \\
\hline
\end{tabular}

goals (or subgoals) were linked to the greatest number of goals (or subgoals). Governance, implementation, and global partnerships have an overarching role and enable realization of all other goals. Following these three goals, Education was found to have an impact on the largest number of other goals (17). Sustained and sustainable economic growth has an impact on 10 other goals; climate change, sustainable agriculture, and sustainable energy each impact nine other goals, and gender equality, employment, and infrastructure impact eight other goals. On the other hand, achieving sustained and sustainable economic growth also relies on the realization of a range of other goals (19). Addressing poverty relies on 16 other goals; hunger, food, security, and nutrition on 15 , and peaceful and inclusive societies on 12 .

Governance and implementation components (SDGs 16, 17) are situated at the top of the diagram. This recognizes the coordinating function of these variables. As the arrows suggest, good governance and implementation are influenced by a number of other variables such as poverty, gender equality, peaceful and inclusive societies, and climate change. The nature and scale of the issues considered within the SDGs also mean that global partnerships (SDG 16) will be critical to achieving the SDGs. The employment and infrastructure goals also make important contributions to a range of other goals, underlining the importance of mechanisms to facilitate implementation. The mapping suggests that gender equality (SDG 5) has an important impact across the SDG system due to the gains made by mobilizing and enabling large parts of the population.

Education has an important impact on multiple parts of the SDG system (see Fig. 2). Stafford-Smith et al. (2016) emphasize the importance of "an agile and integrated global innovation system" for implementing the SDGs. Considering technological innovation separate from other parts of SDG 9 in the conceptual mapping underscores the potential for innovation and advances in technology to create improvements across the SDGs. This underlines the importance of the precautionary principle, which is noticeably absent from the SDGs. Caution also needs to be exercised so that mitigation measures are not overlooked due to faith in technocratic solutions. The grouping of education and technological innovation will be discussed below in overarching direction 5 .

As seen in Fig. 2, climate change (SDG 13) will have detrimental impacts across the social, economic, and environmental components of the SDG system. At the same time, SDG 7 (affordable, reliable, and sustainable modern energy) and SDG12 (ensure sustainable consumption and production patterns) will disproportionately impact many environmental, human wellbeing, and development goals. These goals also have a direct impact on mitigating the impacts and extent of climate change. Reed et al. (2013) have demonstrated that climate change, poverty, land degradation, and sustainable land management are inextricably linked due to climate change impacts on land and water availability for agriculture, while reducing the productivity of fisheries. At the same time, the diagram illustrates connections between the environment-related goals (SDG 6(i), SDG 13, SDG 14) and human well-being.

Industrialization (SDG 9 (ii)), consumption and production (SDG 12), energy (SDG 7), and agriculture (SDG 2(ii) are each important leverage points in their own right and, in turn, form part of a larger process of consumption and production. This is 
explored further in overarching direction 7 below. The conceptual modeling also highlights the importance of these goals not only on the economy but also on natural resources and human wellbeing.

The conceptual mapping suggests that a separate SDG dedicated to cities and settlements (SDG11: inclusive, safe and resilient cities and settlements) could be superfluous once SDGs 5 (gender equality), 10 (inequality within and among countries, power of technocratic solutions), and 16 (peaceful and inclusive societies) are taken into account. Therefore, implementation of work on cities could be streamlined through these goals to see it as a particular contextual lens through which to view integrated implementation of the SDGs.

Figure 2 illustrates how sustained and sustainable growth (SDG 8) and poverty (SDG 1), even under the narrow definition in the final SDG text, are intrinsically linked to the majority of the other components. The mapping highlights how economic growth is dependent on the realization of multiple environmental and social goals. Poverty, for example, has an impact on the economy, while being an important indicator of the state of the economy. Poverty also affects the realization of safe and inclusive cities and settlements (SDG 11) and peaceful and inclusive societies (16(i)). This reinforces the multiple dimensions of poverty and flow on impacts, both positive and negative, of changes to levels of poverty on other areas of the SDGs.

\section{Keyword network analysis}

The network analysis (Jørgensen, unpublished manuscript) yielded multiple insights into the SDGs as a system of targets. First, unifying connections between targets and goals become increasingly evident when focal subjects and the nature of proposed actions are used to characterize targets rather than by the general topics they address (which has dominated previous approaches) (see methods and Jørgensen, unpublished manuscript for examples). Second, incorporating subjects and actions under keywords increases connections across general goal themes. Thus, this helps avoid treating the SDGs as a fragmented agenda of disparate social, economic, environmental, and natural resource issues. Third, the analysis identifies a number of keyword topics that, if addressed successfully across targets, will help achieve a high proportion of the SDGs. This includes, in particular, issues of accessibility, but also women, resources, and finance (Fig. 3). Therefore, the keyword analysis reveals integration across the SDGs that may not be apparent at the goal level or by focusing on general topics. It also suggests leverage points in the form of key subjects (e.g., women) or properties (e.g., resources, finance, and accessibility) that could have disproportional impact on effective implementation of the SDGs.

\section{Identifying integrating goals and targets}

The analysis visualizes crosscutting issues that, if addressed successfully, will help achieve a high proportion of the SDGs, such as issues of access, women, resources, and finance. Four SDGs had two targets including one or more of the top five of highly connected keywords: SDG 9 (industry), SDG 11 (sustainable cities), SDG 13 (climate action), SDG 16 (peace and justice). Six goals had one target: SDG 2 (food security), SDG 3 (health), SDG12 (consumption and production), SDG14 (oceans), SDG8 (decent work), SDG7 (energy) (Jørgensen, unpublished manuscript). Four keywords occurred in more than
10 Goals: "subject" all (15), "subject" national (13), "property" accessibility (12), and "action" ensuring (12). Subject keywords were dominated by keywords signalling universality of the goals, e.g., all, people (9 goals) and global (9) and a focus on women (8). Top character keywords signalled a focus on accessibility (12 goals) and (not surprisingly) sustainability (8 goals) and were otherwise represented by action keywords, including equal representation of promoting (9) and reduction (9). Occurrence of top keywords often overlapped in some of the central targets and complemented each other by covering different parts of the more peripheral target network (e.g., Fig. 3) (Jørgensen, unpublished manuscript).

Women are the nonuniversal subjects mentioned most often across goals, indicating a major need to coordinate actions under multiple goals with a focus on gender equality (Jørgensen, unpublished manuscript). Increasing "access" to various resources and benefits is a striking example of an area that transcends goals and would benefit from a coordinated approach. The issue of access is found in 12 goals in networks based on SDGs 1 to 16.

Integrating goals can be identified as goals containing single targets connecting to in a large proportion of other goals (Jørgensen, unpublished manuscript). Identifying central goals based on single targets should be less prone to artificially ranking the goals with the most targets - and likely most crossgoal connections - as the most central. When this is done for the "challenge"-based network, goals on cities (SDG 11), hunger (SDG 2), health (SDG 3), and economic growth (SDG 8) are identified as the goals containing the most central targets.

In comparison to LeBlanc's analysis, only the goal on economic growth (SDG 8) ranks in the top four in both analyses. When we expand this approach to all keyword categories, goals on peace (SDG 16), climate (SDG 13, with two targets), economic growth (SDG 8), and energy (SDG 7), are ranked as the four most central goals. Again, sharing only the goal on economic growth (SDG 8) with Le Blanc's analysis and interestingly containing both goals from the social (16), economic (8), resource (7), and environmental (13) goal themes. These differences highlights the importance of distinguishing between goals based on their entire set of targets, or a single target, and between central goals based only on "challenges" or a more complete set of characteristics, including "subjects" and the "character" of the actions (Jørgensen, unpublished manuscript).

The network analysis provides an overview of the complex network constituted by the SDGs with the potential to identify new, unappreciated links. This is an important contribution to the understanding of the SDGs because each link may, in the end, show itself as a candidate leverage point to deliver the unprecedented ambitious SDG agenda in 2030.

\section{SEVEN OVERARCHING DIRECTIONS}

Our analyses above have identified the gaps, overlaps, and potential links across the SDGs. From this, we present seven overarching directions (Fig. 4) to highlight where critical focal areas of SDG integration and implementation are needed to support the Sustainable Development end goal defined in this paper. The overarching directions consist primarily of clustering of existing SDGs (Append. 1), with some SDGs appearing across more than one overarching direction. The overarching directions 
Fig. 3. A network of 107 SDG targets connected by shared challenges, subjects, instruments, conditions, actions, and properties. Targets containing a selected subset of keywords that occur across many goals are highlighted in orange, other targets are illustrated in gray.
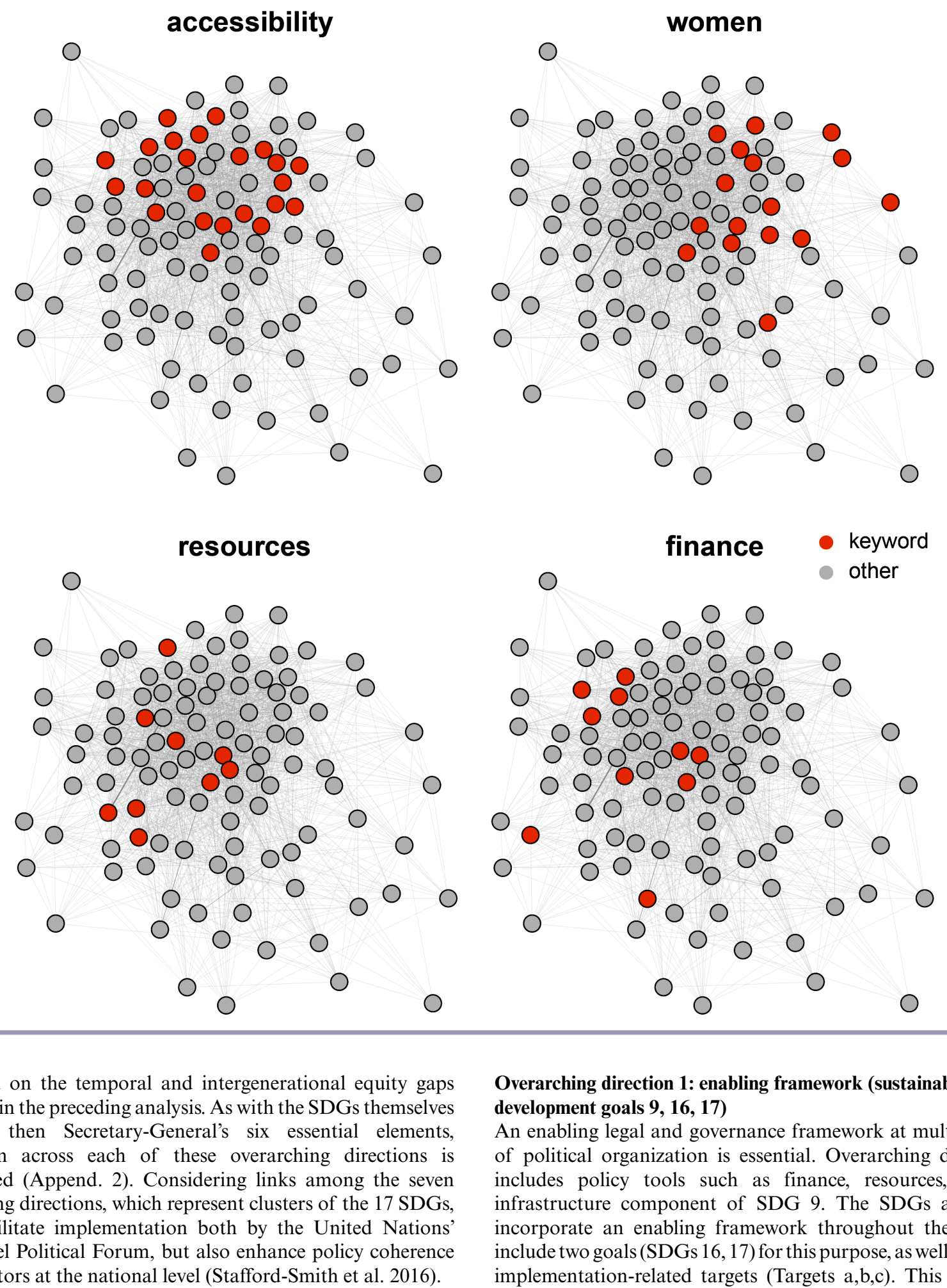

also build on the temporal and intergenerational equity gaps identified in the preceding analysis. As with the SDGs themselves and the then Secretary-General's six essential elements, integration across each of these overarching directions is emphasized (Append. 2). Considering links among the seven overarching directions, which represent clusters of the 17 SDGs, could facilitate implementation both by the United Nations' High-Level Political Forum, but also enhance policy coherence across sectors at the national level (Stafford-Smith et al. 2016).
Overarching direction 1: enabling framework (sustainable development goals 9, 16, 17)

An enabling legal and governance framework at multiple levels of political organization is essential. Overarching direction 1 includes policy tools such as finance, resources, and the infrastructure component of SDG 9. The SDGs attempt to incorporate an enabling framework throughout the text and include two goals (SDGs 16, 17) for this purpose, as well as specific implementation-related targets (Targets a,b,c). This is a good starting point. The discussion above highlights, however, the need 
for a more coordinated framework and a hierarchy of norms. The transfer of financial and other resources and global partnerships are critical to achieving meaningful implementation and ultimately the objective of sustainability. Their importance is supported by the prominence of finance and resources in the network analysis. These purposes are clustered here to avoid unnecessary fragmentation in implementation.

Fig. 4. Required relationships among the seven overarching directions to orient the SDG system toward the sustainable development end goal: at the core, a stable resilient Earth system (OD3) is the foundation for thriving lives and livelihoods (OD2). This influences and is influenced by a sustainable economy (OD 7). Innovation and education (OD6) are required to facilitate integration across the economic, social, and ecological components of sustainable development and to develop mechanisms to simultaneously advance all three components. This is mediated and regulated by an overarching enabling framework (OD1). To achieve the sustainable development end goal intragenerational (OD4) and intergenerational (OD 5) equity need to be included in the implementation of all other ODs, including OD1. Intragenerational equity (OD4) contributes to future intergenerational equity (OD5).

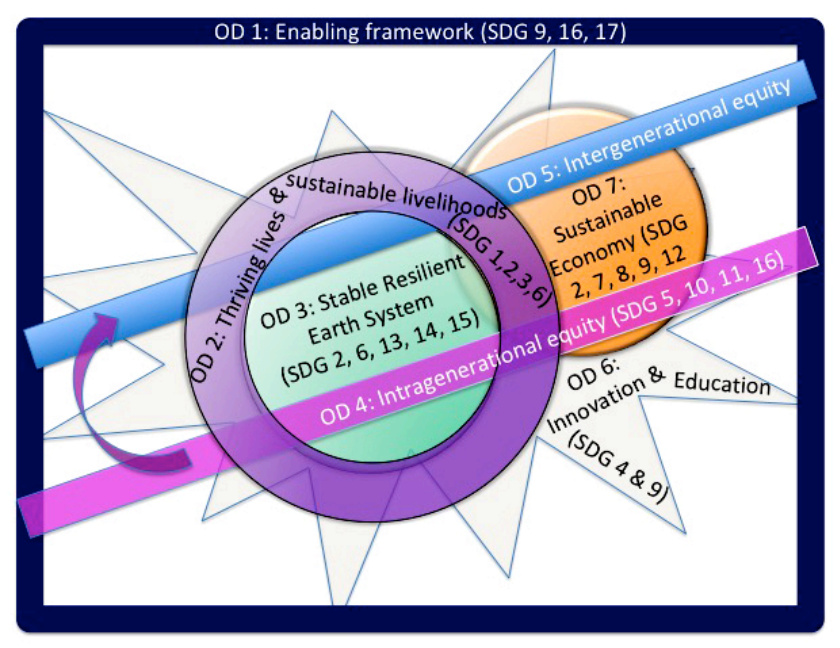

Governance and institutions have an overarching position within the overarching direction framework. This should enable a more coordinated approach to implementation, governance, and institutional structures at national and global levels to support the rest of the overarching direction framework. Completely overturning the current siloed approach could prove unrealistic as compartmentalization reflects the political and institutional realities within international and national systems (Nilsson and Costanza 2015). Therefore, they propose an interlinking approach premised upon the establishment of new processes across sectoral domains at both national and UN levels (Nilsson and Costanza 2015). Successful implementation requires governance that incentivizes sectors and institutions to contribute to SDGs and targets outside their traditional portfolios. Examples include reducing surgical waste in the health sector, mainstreaming gender and equity across sectors, and infrastructure and industrialization that promote or at the very least do not compromise health- or environment-related goals.

Overarching direction 2: thriving lives and sustainable livelihoods (sustainable development goals 1, 2, 3, 6)

More recognition is needed of the interrelationships among SDG1 (poverty), SDG 2 (end hunger, food security, and nutrition), SDG 3 (health), and a component of SDG 6 (clean water). This overarching direction builds on Griggs et al.'s proposed goal of "thriving lives and livelihoods" (Griggs et al. 2013), recognizing the weaknesses of SDG1 with respect to the multiple dimensions of poverty. As discussed above, SDG 1, which aims to address poverty "in all its forms" all over the world, is too broad. Furthermore, the use of income as a focal indicator is inadequate. Our mapping exercise illustrates that meeting SDG 1 requires that most of the other SDGs are also met (after Deacon and St. Clair 2015). Correspondingly, clustering within a wellbeing and livelihoods framework supports Deacon and St. Clair (2015) with respect to the need for multiple measurements to gain an appropriate view of poverty. This clustering shifts the focus beyond conceptualizing poverty "as a disease to be cured" (Brewer 2015 ) to a course of action focused on human well-being through a healthy and sustainable future.

Overarching direction 2 also raises population dynamics to greater prominence within the SDGs. Gains in efficiencies of resource use, with more sustainable production and consumption patterns, will be undermined if human populations continue to grow until the end of the century (Gerland et al. 2014). This complex issue requires a focus on the interconnections among population, education, and gender. Building on the focus on gender equality across the SDGs, a combined focus with universal access to sexual health care, including family planning, in Target 3.7 creates reason for optimism that the existing SDG framework will have some impact on unsustainable human population growth. This is, however, clearly a political and culturally sensitive issue that requires a humane approach to address the challenges of population growth. Overt recognition of population could facilitate strategic and holistic approaches and the pooling of resources to address this issue.

Overarching direction 3: stable resilient earth system (sustainable development goals $2,6,13,14,15$ )

Overarching direction 3 advocates for an integrated conceptualization of the biosphere. Thus, it clusters the environment-related SDGs with the sustainable agriculture component of SDG2 and the sustainable management of freshwater systems component of SDG6. Overarching direction 3 emphasizes the need for greater links across environmental institutions within the goals, paired with links to the processes that impact on the long-term functioning of the Earth system. Overarching direction 3 aligns the SDGs with the planetary boundaries framework and charts a course toward the sustainable development end goal adopted in this paper.

\section{Overarching direction 4: intragenerational equity (sustainable} development goals 5, 10, 11, 16)

Equity is an important focus of the SDGs. Equity appears in multiple SDGs, in particular, equitable education (SDG 4) and equity across genders (SDG 5). The keyword "access" regularly occurred within the network analysis in relation to enabling access to enable equity. The network analysis reinforces the importance 
of gender equity, with the involvement of women identified as an important leverage point for integration across the SDGs. The SDGs also promote inclusive economic growth (SDG 8) and inclusive industrialization (SDG 9). Sustainable development goal 10 specifically calls for reduced inequality across countries, and SDG 16 promotes peaceful and inclusive societies. Clustering equity in an overarching direction highlights intragenerational equity as a crosscutting issue for achieving the SDGs across all sectors.

\section{Overarching direction 5: intergenerational equity}

Intergenerational equity is critical for achieving the end goal for "current and future generations," yet it is noticeably absent within the SDGs. To be truly sustainable, the SDGs require some consideration of a time scale beyond 2030. Protecting Earth's lifesupport systems is central to any strategy aiming to provide future generations with similar opportunities realized by some groups within the current generation (Young et al. 2014). This has profound distributional implications (Young et al. 2014), necessitating a transformative restructuring of current economies and the distribution and creation of wealth. Like intragenerational equity, intergenerational equity requires a crosscutting, cross-sector approach to implementation.

\section{Overarching direction 6: education and innovation (sustainable development goals 4, 9)}

Clustering education (SDG 4) and the innovation component of SDG 9 recognizes the life-long nature of education and its importance in fostering innovation. These issues are critical to facilitate the generation of new knowledge, technologies, and approaches to the unprecedented challenges the SDGs are intended to address. This clustering could also foster learning across current and future practices that have created these challenges.

\section{Overarching direction 7: sustainable economies (sustainable development goals $2,7,8,9,12$ )}

The focus on "sustainable" in this overarching direction emphasizes the need to move from the "sustained and sustainable" growth of SDG7 to meet the sustainable development end goal. Overarching direction 7 integrates the closely aligned sectors of sustainable trade, industry, consumption, production, and energy in a sustainable economy. Here, the importance of an sustainable development end goal is particularly evident to support implementation that does not conflict with the end goal.

Without sustainable consumption and production, reducing the human population is insufficient to address pressing sustainability concerns. Bradshaw and Brook (2014) suggest that considerably larger population sizes could be sustainable with technological advances, such as sustainable energy and closedsystem recycling, which vastly reduces consumption of primary resources. This overarching direction recognizes that universal clean energy (SDG 7) is key to sustainable production, highlighting the interactions among consumption, production, and energy as well as the social gains access to energy provides and the environmental imperative of clean energy. For example, delivering electricity to the $19 \%$ of the world's population who currently do not have access to energy could be achieved with less than a $1 \%$ increase in global $\mathrm{CO}_{2}$ emissions (Raworth 2012). Overarching direction 7 also acknowledges the water-food- energy nexus and the considerations in SDG 2 that promote sustainable agriculture.

Considering the links identified through the conceptual mapping, this overarching direction stresses integration of environmental sustainability within economic activities and emphasizes the need to link this cluster to the cause-and-effect implications across social and environmental goals. This overarching direction also emphasizes a move beyond gross domestic product as a proxy for an overarching goal for the SDGs (Costanza 2014) and a new approach to measuring economic progress (Kubisczweski et al. 2013).

\section{CONCLUSIONS}

The ambitious nature of the SDGs creates enormous implementation challenges at global, national, and local scales. The sheer number of goals, targets and indicators and the lack of clearly identified links or an ultimate end goal risk undermining not only the SDG process but also progress toward sustainable development in the Anthropocene. Effective implementation of the SDGs will require States to attend to trade-offs and overlaps. International negotiations, however, tend to gloss over these issues (Nilsson et al. 2016). Therefore, Nilsson et al. (2016) warn that failure to address trade-offs and overlaps or simply "ticking off" targets, risks perverse outcomes.

Prior to the launch of the SDGs, Griggs et al. (2014) called for the application of systems judgement to select a necessary and sufficient set of goals. Such judgement remains essential to ensure meaningful implementation of the SDGs at all governance scales. This paper argues that the complexity of the multiple interacting components of sustainable development mean that an end goal and systems analysis are critical to managing trade-offs, identifying leverage points, supporting effective implementation of the SDGs, and ultimately achieving sustainable development in the Anthropocene. Interpretation of each of the goals and targets discussed in this paper through the lens of Griggs et al.'s (2013) redefinition of sustainable development would apply a qualification to each of these goals so that the aspirations of these goals and targets are implemented only to the extent to which they are not in conflict with the end goal. Failure to consider these provisions in light of the end goal and not actively addressing the essential issue of integration would undermine long-term sustainability.

When viewed through the lens of an end goal, many weaknesses in the SDG framework come to light. This includes the narrow conceptualization of poverty; the misguided objective of sustained growth; the absence of a key global actor (the corporation); the haphazard inclusion of international law; and two critical omissions (population dynamics and intergenerational equity). Our keyword analysis reveals a more integrated SDG system than what appears at face value. Access, resources, finance, and women could be four key leverage points through which to implement the SDGs in an integrated fashion. Finally, our combined analysis points to seven overarching directions (six clusters of existing SDGs and the additional overarching direction of intergenerational equity) through which integrated implementation of the SDGs and progress toward sustainability in the Anthropocene could be achieved. 
The SDGs must be considered beyond their 15-yr lifespan if they are to contribute to sustainability in the face of global environmental change. Effective implementation requires an integrated approach across and within the economic, social, and ecological components of sustainable development. Ensuring a stable resilient Earth system needs to be at the core of decision making. At the same time, equity for current and future generations should transcend all efforts to achieve the SDGs. Support for innovation and capacity building through education will also be fundamental to progress. Finally, the sustainable development end goal requires robust, cross-scale, and crosssectoral regulatory and institutional frameworks that recognize the complex interactions across the components of sustainable development.

Responses to this article can be read online at: http://www.ecologyandsociety.org/issues/responses. $\mathrm{php} / 10182$

\section{Acknowledgments:}

The authors thank the Environment Institute, University of Adelaide and Professor Bob Hill for financial support. The authors also would like to thank the International Council for Science (ICSU), the International Social Science Council (ISSC), the German Research Foundation (DFG), and Future Earth for enabling the collaboration between the authors.

\section{LITERATURE CITED}

Abson, D. J., J. Fischer, J. Leventon, J. Newig, T. Schomerus, U. Vilsmaier, H. von Wehrden, P. Abernethy, C. D. Ives, N. W. Jager, and D. J. Lang. 2017. Leverage points for sustainability transformation. Ambio 406:30-39. http://dx.doi.org/10.1007/ s13280-016-0800-y

Arthur, W. B. 1994. Increasing returns and path dependence in the economy. University of Michigan Press, Ann Arbor, Michigan, USA. http://dx.doi.org/10.3998/mpub.10029

Ban, K. M. 2014. The road to dignity by 2030:ending poverty, transforming all lives and protecting the planet-synthesis report of the Secretary-General on the Post-2015 Agenda. United Nations, New York, New York, USA.

Banson, K. E., N. C. Nguyen, O. J. Bosch, and T. V. Nguyen. 2015. A systems thinking approach to address the complexity of agribusiness for sustainable development in Africa: a case study in Ghana. Systems Research and Behavioral Science 32: 672-688. http://dx.doi.org/10.1002/sres.2270

Bongaarts, J., and S. Sinding. 2011. Population policy in transition in the developing world. Science 333: 574-576. http://dx.doi. org/10.1126/science. 1207558

Bradshaw, C. J. A., and B. W. Brook. 2014. Human population reduction is not a quick fix for environmental problems. Proceedings of the National Academy of Sciences111(6): 1661016615. http://dx.doi.org/10.1073/pnas.1410465111
Brewer, J. 2015. Who framed global development? Language analysis of the sustainable development goals. [online] URL:http:// www.slideshare.net/joebrewer31/who-framed-global-development

Chambers, R., and G. Conway. 1991. Sustainable rural livelihoods: practical concepts for the 21st century. IDS Discussion Paper 296, Institute of Development Studies, University of Sussex, Brighton, UK.

Clayton, A. M. H., and N. J. Radcliffe. 1996. Sustainability-a systems approach. Earthscan, London, UK.

Cohen, J. 2003. Human population: the next half century. Science 302: 11721175. http://dx.doi.org/10.1126/science.1088665

Costanza, R., I. Kubiszewski, E. Giovannini, H. Lovins, J. McGlade, and K. E. Pickett. 2014. Time to leave GDP behind. Nature 205:203-285.

Costanza, R., J. McGlade, H. Lovins, and I. Kubiszewski. 2015. An overarching goal for the UN sustainable development goals. Solutions 5(4): 13-16.

Dasgupta, P. 2001. Human wellbeing and the natural environment. Oxford University Press, Oxford, UK. http://dx.doi.org/https:// doi.org/10.1093/0199247889.001.0001

Deacon, B., and A. St. Clair. 2015. Goal 1-end poverty in all its forms everywhere. Pages 15-18 in International Council for Science (ICSU), International Social Science Council (ISSC). Review of the sustainable development goals: the science perspective. International Council for Science, Paris, France.

Denzin, N. K. 1989. The research act: a theoretical introduction to sociological methods. Prentice Hall, Upper Saddle River, New Jersey, USA.

Fischer, J., T. A. Gardner, E. M. Bennett, P. Balvanera, R. Biggs, S. Carpenter, T. Daw, C. Folke, R. Hill, and T. P. Hughes. 2015. Advancing sustainability through mainstreaming a socialecological systems perspective. Current Opinion in Environmental Sustainability 14: 144-149. http://dx.doi.org/10.1016/j.cosust.2015.06.002

Folke, C., S. R. Carpenter, B. Walker, M. Scheffer, T. Chapin, and J. Rockström. 2010. Resilience thinking: integrating resilience, adaptability and transformability. Ecology and Society 15: 20. http://dx.doi.org/10.5751/ES-03610-150420

French, D. 2010. Sustainable development. Chapter 3 in M. Fitzmaurice, D. M. Ong, and P. Merkouris, editors. Research handbook on international environmental law. Edward Elgar Publishing, Cheltenham, UK. http://dx.doi.org/10.4337/978184$\underline{9807265.00011}$

Fukuda-Parr, S. 2014. Global goals as a policy tool: intended and unintended consequences. Journal of Human Development and Capabilities 15 (2-3): 118-131. http://dx.doi.org/10.1080/19452$\underline{829.2014 .910180}$

Fürsich, E. 2009. In defense of textual analysis: restoring a challenged method for journalism and media studies. Journalism Studies 10(2): 238-252. http://dx.doi.org/10.1080/14616700802374050

Gerland, P., A. E. Raftery, H. Ševčíková, N. Li, D. Gu, T. Spoorenberg, L. Alkema, B. K. Fosdick, J. Chunn, N. Lalic, G. Bay, T. Buettner, G. K. Heilig, and J. Wilmoth. 2014. World 
population stabilization unlikely this century. Science 346(6206): 234. http://dx.doi.org/10.1126/science.1257469

Griggs, D., M. Stafford-Smith, O. Gaffney, J. Rockström, M. C. Öhman, P. Shyamsundar, W. Steffen, G. Glaser, N. Kanie, and I. Noble. 2013. Sustainable development goals for people and planet. Nature 495(7441): 305-307. http://dx.doi.org/10.1038/495305a

Griggs, D., M. Stafford-Smith, J. Rockström, M. C. Öhman, O. Gaffney, G.Glaser, N. Kanie, I. Noble, W. Steffen, and P. Shyamsundar. 2014. An integrated framework for sustainable development goals. Ecology and Society 19(4): 49. http://dx.doi. org/10.5751/ES-07082-190449

Hjorth, P., and A. Bagheri. 2006. Navigating towards sustainable development: a systems dynamics approach. Futures 38:74-92. http://dx.doi.org/10.1016/j.futures.2005.04.005

International Council of Science (ICSU), International Social Science Council (ISSC). 2015. Review of the sustainable development goals: the science perspective. ICSU/ISSC, Paris, France.

Kickert, W. J. M., E.-H. Klijn, and J. F. M. Koppenjan, editors. 1999. Managing complex networks, strategies for the public sector. Sage Publications, London, UK; Thousand Oaks, California, USA.

Kubiszewski, I., R. Costanza, C. Franco, P. Lawn, J. Talberth, T. Jackson, and C. Aylmer. 2013. Beyond GDP: measuring and achieving global genuine progress. Ecological Economics 93:5768. http://dx.doi.org/10.1016/j.ecolecon.2013.04.019

Le Blanc, D. 2015. Towards integration at last? The sustainable development goals as a network of targets. Sustainable Development 23(3). http://dx.doi.org/10.1002/sd.1582

Liu, J., H. Mooney, V. Hull, S. J. Davis, J. Gaskell, T. Hertel, J. Lubchenco, K. C. Seto, P. Gleick, C. Kremen, and S. Li. 2015. Systems integration for global sustainability. Science 347(6225): 1258832. http://dx.doi.org/10.1126/science.1258832

Lutz, W. 2009. Sola schola et sanitate: human capital as the root cause and priority for international development? Philosophical Transactions of the Royal Society B 364: 3031-3047. http://dx.doi. org/https://doi.org/10.1098/rstb.2009.0156

McCrary, J., and H. Royer. 2011. The effect of female education on fertility and infant health: evidence from school entry policies using exact date of birth. American Economic Review101(1):158195. http://dx.doi.org/https://doi.org/10.1257/aer.101.1.158

Meadows, D. 1999. Leverage points: places to intervene in a system. The Sustainability Institute, Hartland, Vermont, USA.

Meadows, D. 2008. Thinking in systems: a primer. Chelsea Green Publishing, White River Junction, Vermont, USA.

Morse, S., and N. McNamara. 2013a. Sustainable livelihood approach-a critique of theory and practice. Springer, Dordrecht, The Netherlands. http://dx.doi.org/https://doi.org/10.1007/978-94-007-6268-8

Morse, S., and N. McNamara. 2013b. The theory behind the sustainable livelihood approach. Pages 15-60 in S. Morse and N. McNamara. Sustainable livelihood approach - a critique of theory and practice. Springer, DordrechtThe Netherlands. http://dx.doi. org/https://doi.org/10.1007/978-94-007-6268-8 2
Newell, B., D. M. Marsh, and D. Sharma. 2011. Enhancing the resilience of the Australian national electricity market: taking a systems approach in policy development, Ecology and Society 16 (2): 15. http://dx.doi.org/10.5751/ES-04132-160215

Nilsson, M., and R. Costanza. 2015. Overall framework for the sustainable development goals. Pages 7-12 in ICSU, ISSC. Review of the sustainable development goals: the science perspective. ICSU, Paris, France.

Nilsson, M., D. Griggs and M. Visbeck. 2016. Map the interactions between sustainable development goals. Nature 534:320-322.

Olsen, W. 2004. Triangulation in social research: qualitative and quantitative methods can really be mixed. Pages 103-121 in M. Holborn. Developments in sociology. Causeway Press, Ormskirk, UK.

O’Neill, B. C., B. Liddle, L. Jiang, K. R. Smith, S. Pachauri, M. Dalton, and R. Fuchs. 2012. Demographic change and carbon dioxide emissions Lancet 380(9837):157-164. http://dx.doi.org/ https://doi.org/10.1016/S0140-6736(12)60958-1

Ostrom, E. 2009. A general framework for analyzing sustainability of social-ecological systems. Science 325: 1931. http://dx.doi.org/10.1126/science.1172133

Pahl-Wostl, C. 2007. Transitions towards adaptive management of water facing climate and global change. Water Resources Management 21:49-62. http://dx.doi.org/10.1007/s11269-006-9040-4

Permanent Court of International Justice (PCIJ). 1927. The case of the S.S. "Lotus" (France vs. Turkey). Series A, number 10, A. W. Sijthoff's Publishing Company, Leyden, The Netherlands.

Phelps, J., L. R. Carrasco, E. L. Webb, L. P. Koh, and U. Pascual. 2013. Agricultural intensification escalates future conservation costs. Proceedings of the National Academy of Sciences 110:76017606. http://dx.doi.org/10.1073/pnas. 1220070110

Proust, K., B. Newell, H. Brown, A. Capone, C. Browne, A. Burton, J. Dixon, L. Mu, and M. Zarafu. 2012. Human health and climate change: leverage points for adaptation in urban environments. International Journal of Environmental Research and Public Health 9(6):2134-2158. http://dx.doi.org/10.3390/ ijerph9062134

Raworth, K. 2012. A safe and just space for humanity. Can we live within the doughnut? Oxfam Discussion Paper, Oxfam, Oxford, UK.

Reed, M. S, G. Podesta, I. Fazey, N. Geeson, R. Hessel, K. Hubacek, D. Letson, D. Nainggolan, C. Prell, M. G. Rickenbach, C. Ritsema, G. Schwilch, L. C. Stringer, and A. D. Thomas. 2013. Combining analytical frameworks to assess livelihood vulnerability to climate change and analyse adaptation options. Ecological Economics 94:66-77. http://dx.doi.org/10.1016/j. ecolecon.2013.07.007

Rockström, J., W. Steffen, K. Noone, A. Persson, F. S. Chapin, III, E. Lambin, T. M. Lenton, M. Scheffer, C. Folke, H. Schellnhuber, B. Nykvist, C. A. De Wit, T. Hughes, S. van der Leeuw, H. Rodhe, S. Sorlin, P. K. Snyder, R. Costanza, U. Svedin, M. Falkenmark, L. Karlberg, R. W. Corell, V. J. Fabry, J. Hansen, B. Walker, D. Liverman, K. Richardson, P. Crutzen, and J. Foley. 2009. Planetary boundaries: exploring the safe operating space 
for humanity. Ecology and Society 14(2): 32. http://dx.doi. org/10.5751/ES-03180-140232

Sands, P. 2003. Principles of international environmental law. Cambridge University Press, Cambridge, UK. http://dx.doi.org/ https://doi.org/10.1017/CBO9780511813511

Schrijver, N. 2002. ILA New Delhi declaration of principles of international law relating to sustainable development. Netherlands Law Review 49:299-305. http://dx.doi.org/10.1017/ $\underline{\mathrm{S} 0165070 \mathrm{X} 00000528}$

Sen, A. 1999. Development as freedom. Oxford University Press, Oxford, UK.

Skirbekk, V. 2008 Fertility trends by social status. Demographic Research 18:145-180. http://dx.doi.org/https://doi.org/10.4054/ DemRes.2008.18.5

Stafford-Smith, M., D. Griggs, O. Gaffney, F. Ullah, B. Reyers, N. Kanie, B. Stigson, P. Shrivastava, M. Leach, and D.. O'Connell, D. 2016. Integration: the key to implementing the sustainable development goals. Sustainability Science 12(6):911-919. http:// dx.doi.org/10.1007/s11625-016-0383-3

Steffen, W., K. Richardson, J. Rockström, S. E. Cornell, I. Fetzer, E. M. Bennett, R. Biggs, S. R.Carpenter, W. de Vries, C. A. de Wit, C. Folke, D. Gerten, J. Heinke, G. M. Mace, L. M. Persson, V. Ramanathan, B. Reyers, and S. Sörlin. 2015. Planetary boundaries: guiding human development on a changing planet. Science 347(6223): 736. http://dx.doi.org/10.1126/science.1259855

United Nations. 2012. Rio+20: the future we want: outcome document adopted at Rio+20. Adoption resolution, 66th session. United Nations, New York, New York, USA. [online] URL: http://www.un.org/ga/search/view doc.asp?symbol=A/ $\underline{\mathrm{RES} / 66 / 288 \& \text { Lang }=\mathrm{E}}$.

United Nations. 2015. Transforming our world: the 2030 agenda for sustainable development. Adoption resolution, 70th session. United Nations, New York, New York, USA. [online] URL: http://www.un.org/ga/search/view_doc.asp?symbol=A/RES/70/1\&Lang= E.

World Commission on Environment and Development. 1987. Report of the World Commission on Environment and Development: our common future. Oxford University Press, Oxford, UK.

Weitz, N., M. Nilsson, and M. Davis. 2014. A nexus approach to the post-2015 agenda: formulating integrated water, energy, and food SDGs. SAIS Review of International Affairs 34(2):37-50. http://dx.doi.org/https://doi.org/10.1353/sais.2014.0022

Yamada, T. 2017. Corporate water stewardship: lessons for goalbased hybrid governance. Pages 187-210 in S. Kanie and F. Biermann, editors. Governing through goals-sustainable development goals as governance innovation. MIT Press, Cambridge, Massachusetts, USA; London, UK. http://dx.doi. org $/ 10.7551 / \mathrm{mitpress} / 9780262035620.003 .0008$

Young, O. R., A. Underdal, N. Kanie, S. Andresen, S. Bernstein, F. Biermann, J. Gupta, P. M. Haas, M. Iguchi, M. Kok, M. Levy, M. Nilsson, L. Pintér, and C. Stevens. 2014. Earth system challenges and a multi-layered approach for the sustainable development goals. Post 2015/UNU-IAS Policy Brief 1, United Nations University Institute for the Advanced Study of Sustainability, Tokyo, Japan. 
Appendix 1. Sub-systems and sub-goals of the SDGs

\begin{tabular}{|c|c|c|}
\hline 4 Sub-systems & Sustainable Development Goals & Sub-goals \\
\hline \multirow[t]{10}{*}{ 1. Society } & $\begin{array}{l}\text { SDG 1: End poverty in all its forms } \\
\text { everywhere }\end{array}$ & \\
\hline & $\begin{array}{l}\text { SDG 2: End hunger, achieve food security } \\
\text { and improved nutrition and promote } \\
\text { sustainable agriculture } \\
\text { Mapped as SDG } 2 \text { (i) Food security and } \\
\text { nutrition; and } \\
\text { SDG 2(ii) sustainable agriculture }\end{array}$ & $\begin{array}{l}\text { SDG 2(i) included in 'Society' sub- } \\
\text { system }\end{array}$ \\
\hline & $\begin{array}{l}\text { SDG 3: Ensure healthy lives and promote } \\
\text { well-being for all at all ages. }\end{array}$ & $\begin{array}{l}\text { Mapped as a health goal. Though } \\
\text { well-being is in the title the Targets } \\
\text { of SDG } 3 \text { refer to health in a narrow } \\
\text { sense and not well-being more } \\
\text { broadly. }\end{array}$ \\
\hline & $\begin{array}{l}\text { SDG 4: Ensure inclusive and equitable } \\
\text { quality education and promote lifelong } \\
\text { learning and opportunities for all. }\end{array}$ & \\
\hline & $\begin{array}{l}\text { SDG 5: Achieve gender equality and } \\
\text { empower all women and girls }\end{array}$ & \\
\hline & $\begin{array}{l}\text { SDG 6: Ensure availability and sustainable } \\
\text { management of water and sanitation for all } \\
\text { Mapped as SDG 6(i) Water availability } \\
\text { and sustainable management and SDG (ii) } \\
\text { Sanitation. }\end{array}$ & $\begin{array}{l}\text { SDG 6(ii) included in 'Society' sub- } \\
\text { system. }\end{array}$ \\
\hline & $\begin{array}{l}\text { SDG 10: Reduce inequality within and } \\
\text { among countries }\end{array}$ & \\
\hline & $\begin{array}{l}\text { SDG 11: Make cities and human } \\
\text { settlements inclusive, safe, resilient and } \\
\text { sustainable. }\end{array}$ & \\
\hline & $\begin{array}{l}\text { SDG 16: Promote peaceful and inclusive } \\
\text { societies for sustainable development, } \\
\text { provide access to justice for all and build } \\
\text { effective, accountable and inclusive } \\
\text { institutions at all levels. } \\
\text { Mapped as SDG16(i) Peaceful and } \\
\text { inclusive societies for sustainable } \\
\text { development; } \\
\text { SDG } 16 \text { (ii) access to justice for all and } \\
\text { effective, accountable and inclusive } \\
\text { institutions at all levels }\end{array}$ & $\begin{array}{l}\text { SDG 16(i) included in 'Society' sub- } \\
\text { system. }\end{array}$ \\
\hline & $\begin{array}{l}\text { SDG 17: Strengthen the means of } \\
\text { implementation and revitalise the global } \\
\text { partnership for sustainable development. } \\
\text { Mapped as SDG 17(i) Strengthen means } \\
\text { of implementation and SDG 17(ii) } \\
\text { Revitalise the Global partnership for } \\
\text { sustainable development }\end{array}$ & $\begin{array}{l}\text { Goal } 17 \text { (ii) included in 'Society' sub- } \\
\text { system. }\end{array}$ \\
\hline 2. Economy & SDG 2: End hunger, achieve food security & Goal 2 (ii) included in 'economy' \\
\hline
\end{tabular}




\begin{tabular}{|c|c|c|}
\hline & $\begin{array}{l}\text { and improved nutrition and promote } \\
\text { sustainable agriculture } \\
\text { Mapped as SDG } 2 \text { (i) Food security and } \\
\text { nutrition; and } \\
\text { SDG 2(ii) sustainable agriculture }\end{array}$ & sub-system. \\
\hline & SDG 7: Sustainable Energy & \\
\hline & $\begin{array}{l}\text { SDG 8: Promote sustained, inclusive and } \\
\text { sustainable economic growth, full and } \\
\text { productive employment and decent work } \\
\text { for all. } \\
\text { Mapped as SDG 8(i) sustained, inclusive } \\
\text { and sustainable economic growth and } \\
\text { SDG 8(ii) full and productive employment } \\
\text { and decent work. }\end{array}$ & $\begin{array}{l}\text { Both included in 'economy' sub- } \\
\text { system but separated to explore links } \\
\text { and influences across each. }\end{array}$ \\
\hline & $\begin{array}{l}\text { SDG 9: Build resilient infrastructure, } \\
\text { promote inclusive and sustainable } \\
\text { industrialization and foster innovation. } \\
\text { Mapped as SDG } 9 \text { (i) resilient } \\
\text { infrastructure; (ii) inclusive and } \\
\text { sustainable industrialisation; (iii) } \\
\text { innovation. }\end{array}$ & $\begin{array}{l}\text { All included in 'economy' sub- } \\
\text { system but separated to explore links } \\
\text { and influences across the } 3 \text {. }\end{array}$ \\
\hline & $\begin{array}{l}\text { SDG12: Ensure sustainable consumption } \\
\text { and production patterns. }\end{array}$ & \\
\hline \multirow[t]{4}{*}{$\begin{array}{l}\text { 3. Natural } \\
\text { Environment }\end{array}$} & $\begin{array}{l}\text { SDG6: Ensure availability and sustainable } \\
\text { management of water and sanitation for all } \\
\text { Mapped as SDG 6(i) Water availability } \\
\text { and sustainable management and SDG } 6 \\
\text { (ii) Sanitation. }\end{array}$ & $\begin{array}{l}\text { SDG 6(i) included in 'environment' } \\
\text { sub-system. }\end{array}$ \\
\hline & $\begin{array}{l}\text { SDG13: Take urgent action to combat } \\
\text { climate change and its impacts }\end{array}$ & \\
\hline & $\begin{array}{l}\text { SDG 14: Conserve and sustainably use the } \\
\text { oceans, seas and marine resources for } \\
\text { sustainable development. }\end{array}$ & \\
\hline & $\begin{array}{l}\text { SDG15: Protect, restore and promote } \\
\text { sustainable use of terrestrial ecosystems, } \\
\text { sustainably manage forests, combat } \\
\text { desertification, and halt and reverse land } \\
\text { degradation and halt biodiversity loss. }\end{array}$ & \\
\hline \multirow[t]{2}{*}{ 4. Governance } & $\begin{array}{l}\text { SDG16: Promote peaceful and inclusive } \\
\text { societies for sustainable development, } \\
\text { provide access to justice for all and build } \\
\text { effective, accountable and inclusive } \\
\text { institutions at all levels. } \\
\text { Mapped as SDG 16(i) Peaceful and } \\
\text { inclusive societies for sustainable } \\
\text { development; } \\
\text { SDG } 16 \text { (ii) access to justice for all and } \\
\text { effective, accountable and inclusive } \\
\text { institutions at all levels }\end{array}$ & $\begin{array}{l}\text { SDG } 16 \text { (ii) included in the } \\
\text { 'governance' sub-system. }\end{array}$ \\
\hline & SDG 17: Strengthen the means of & SDG 17 (i) included in the \\
\hline
\end{tabular}




\begin{tabular}{|l|l|l|}
\hline & $\begin{array}{l}\text { implementation and revitalise the global } \\
\text { partnership for sustainable development. } \\
\text { Mapped as SDG 17(i) Strengthen means } \\
\text { of implementation and SDG 17(ii) } \\
\text { Revitalise the Global partnership for } \\
\text { sustainable development }\end{array}$ & \\
\hline
\end{tabular}




\begin{tabular}{|c|c|c|}
\hline $\begin{array}{l}7 \text { Overarching } \\
\text { Directions }\end{array}$ & $\begin{array}{c}\text { Secretary-General's } 6 \\
\text { essential elements }\end{array}$ & Sustainable Development Goals \\
\hline \multirow[t]{3}{*}{$\begin{array}{l}\text { OD1. Enabling } \\
\text { framework }\end{array}$} & \multirow{3}{*}{$\begin{array}{l}\text { Partnership: to catalyse global } \\
\text { solidarity for sustainable } \\
\text { development. } \\
\text { Justice: to promote safe and } \\
\text { peaceful societies, and strong } \\
\text { institutions }\end{array}$} & $\begin{array}{l}\text { SDG 9: Build resilient infrastructure, promote } \\
\text { inclusive and sustainable industrialization and } \\
\text { foster innovation. }\end{array}$ \\
\hline & & $\begin{array}{l}\text { SDG 16: Promote peaceful and inclusive } \\
\text { societies for sustainable development, provide } \\
\text { access to justice for all and build effective, } \\
\text { accountable and inclusive institutions at all } \\
\text { levels. }\end{array}$ \\
\hline & & $\begin{array}{l}\text { SDG 17: Strengthen the means of } \\
\text { implementation and revitalise the global } \\
\text { partnership for sustainable development. }\end{array}$ \\
\hline \multirow{4}{*}{$\begin{array}{l}\text { OD2. Thriving lives } \\
\text { and sustainable } \\
\text { livelihoods }\end{array}$} & \multirow{4}{*}{$\begin{array}{l}\text { People: to ensure healthy lives, } \\
\text { knowledge, and the inclusion } \\
\text { of women and children. } \\
\text { Prosperity: to grow a strong, } \\
\text { inclusive, and transformative } \\
\text { economy. }\end{array}$} & $\begin{array}{l}\text { SDG 1: End poverty in all its forms } \\
\text { everywhere }\end{array}$ \\
\hline & & $\begin{array}{l}\text { SDG 2: End hunger, achieve food security } \\
\text { and improved nutrition and promote } \\
\text { sustainable agriculture }\end{array}$ \\
\hline & & $\begin{array}{l}\text { SDG 3: Ensure healthy lives and promote } \\
\text { well-being for all at all ages. }\end{array}$ \\
\hline & & $\begin{array}{l}\text { SDG 6: Ensure availability and sustainable } \\
\text { management of water and sanitation for all }\end{array}$ \\
\hline \multirow[t]{5}{*}{$\begin{array}{l}\text { OD3. Stable resilient } \\
\text { earth systems }\end{array}$} & \multirow[t]{5}{*}{$\begin{array}{l}\text { Planet: to protect our } \\
\text { ecosystems for all societies and } \\
\text { our children. }\end{array}$} & $\begin{array}{l}\text { SDG 2: End hunger, achieve food security } \\
\text { and improved nutrition and promote } \\
\text { sustainable agriculture. }\end{array}$ \\
\hline & & $\begin{array}{l}\text { SDG 6: Ensure availability and sustainable } \\
\text { management of water and sanitation for all }\end{array}$ \\
\hline & & $\begin{array}{l}\text { SDG13: Take urgent action to combat climate } \\
\text { change and its impacts. }\end{array}$ \\
\hline & & $\begin{array}{l}\text { SDG 14: Conserve and sustainably use the } \\
\text { oceans, seas and marine resources for } \\
\text { sustainable development. }\end{array}$ \\
\hline & & $\begin{array}{l}\text { SDG15: Protect, restore and promote } \\
\text { sustainable use of terrestrial ecosystems, } \\
\text { sustainably manage forests, combat } \\
\text { desertification, and halt and reverse land } \\
\text { degradation and halt biodiversity loss. } \\
\end{array}$ \\
\hline \multirow[t]{2}{*}{$\begin{array}{l}\text { OD4. Intra-generational } \\
\text { equity }\end{array}$} & \multirow{2}{*}{$\begin{array}{l}\text { Dignity: to end poverty and } \\
\text { fight inequality. } \\
\text { People: to ensure healthy lives, } \\
\text { knowledge, and the inclusion } \\
\text { of women and children. }\end{array}$} & $\begin{array}{l}\text { SDG 5: Achieve gender equality and } \\
\text { empower all women and girls }\end{array}$ \\
\hline & & $\begin{array}{l}\text { SDG 10: Reduce inequality within and among } \\
\text { countries }\end{array}$ \\
\hline
\end{tabular}




\begin{tabular}{|c|c|c|}
\hline & & $\begin{array}{l}\text { SDG 11: Make cities and human settlements } \\
\text { inclusive, safe, resilient and sustainable. }\end{array}$ \\
\hline & & $\begin{array}{l}\text { SDG 16: Promote peaceful and inclusive } \\
\text { societies for sustainable development, provide } \\
\text { access to justice for all and build effective, } \\
\text { accountable and inclusive institutions at all } \\
\text { levels. }\end{array}$ \\
\hline $\begin{array}{l}\text { OD 5: Intergenerational } \\
\text { equity }\end{array}$ & N/A & N/A \\
\hline \multirow[t]{2}{*}{$\begin{array}{l}\text { OD6: Innovation and } \\
\text { education }\end{array}$} & \multirow{2}{*}{$\begin{array}{l}\text { People: to ensure healthy lives, } \\
\text { knowledge, and the inclusion } \\
\text { of women and children. } \\
\text { Prosperity: to grow a strong, } \\
\text { inclusive, and transformative } \\
\text { economy. }\end{array}$} & $\begin{array}{l}\text { SDG 4: Ensure inclusive and equitable quality } \\
\text { education and promote lifelong learning and } \\
\text { opportunities for all. }\end{array}$ \\
\hline & & $\begin{array}{l}\text { SDG 9: Build resilient infrastructure, promote } \\
\text { inclusive and sustainable industrialization and } \\
\text { foster innovation. }\end{array}$ \\
\hline \multirow[t]{5}{*}{$\begin{array}{l}\text { OD7. Sustainable } \\
\text { economies }\end{array}$} & \multirow[t]{5}{*}{$\begin{array}{l}\text { Prosperity: to grow a strong, } \\
\text { inclusive, and transformative } \\
\text { economy. }\end{array}$} & $\begin{array}{l}\text { SDG 2: End hunger, achieve food security } \\
\text { and improved nutrition and promote } \\
\text { sustainable agriculture }\end{array}$ \\
\hline & & $\begin{array}{l}\text { SDG 7: Ensure access to affordable, reliable, } \\
\text { sustainable and modern energy for all. }\end{array}$ \\
\hline & & $\begin{array}{l}\text { SDG 8: Promote sustained, inclusive and } \\
\text { sustainable economic growth, full and } \\
\text { productive employment and decent work for } \\
\text { all. }\end{array}$ \\
\hline & & $\begin{array}{l}\text { SDG 9: Build resilient infrastructure, promote } \\
\text { inclusive and sustainable industrialization and } \\
\text { foster innovation. }\end{array}$ \\
\hline & & $\begin{array}{l}\text { SDG 12: Ensure sustainable consumption and } \\
\text { production patterns. }\end{array}$ \\
\hline
\end{tabular}

